\title{
Note to the Reader
}

The documents translated, paraphrased, and summarized in this book span almost 150 years. The Spanish (and French) texts produced during this period reflect deep changes in colonial paradigms, personal worldviews, and cultural and linguistic backgrounds as well as phonetic and lexical variations exhibited by a language searching for uniformity and standards. Add to these difficulties the physical condition of the documents, particularly the faded and almost illegible copies, and it becomes easy to understand why most scholars and translators choose to file away textual edges and produce a cohesive and seamless text, leading the reader to assume a textual clarity and transparency of meaning that are frequently illusory.

These problems are most evident in the translations of source material published during the late nineteenth and early twentieth centuries, because that was a period of frenetic efforts to make known a history hereto unknown or disregarded. Scholars (and their translators) such as Bancroft, Bolton, and Castañeda (not to single out anyone but to name just the most prominent) provided historians, anthropologists, and ethnohistorians not just with translated texts but also with intellectual leadership. Later, few scholars revisited or questioned the original translations and so reproduced, indefinitely, whatever errors, omissions, and misconceptions were present in the earlier works. Also, the clarity of the original texts, their immediacy, and the correctness of interpretation made by earlier scholars were (and are) taken for granted. Eugene Bolton would certainly be the first to question such research practices.

Unlike other scholars I chose to treat the archival documents in this book by keeping as close to the actual text as possible, and to maintain the language "flavor" and textual idiosyncrasies of each writer. This effort extends to phonetic, lexical, and grammatical choices. This practice results in texts whose structure feels awkward and foreign (as it should). Texts that I have paraphrased or summarized will, as far as possible, keep close to the word choice of the original writer, particularly if the words relate to cultural information (i.e., tejado dwellings versus zacate huts) or controversial issues (such as Fr. Manuel's trip to Texas).

As for the documents that I translated for the first time, or that I re-translated (specifi- 
cally the travel diaries), I elected to translate the text by retelling it as an outside observer (participant-observer). This device allowed me to reorder the sentences and contextualize the subject being discussed without changing the information provided. This strategy also let me interject the travel diaries and hopefully produced a more fluid narrative without smoothing the incongruencies of the original text. To give the reader a concise idea of problems and the strategies I adopted, below is an example of the Mendoza-Lopez diary transcribed from the transcription available in the Center for American History:

$==$ En veinte dias del dho mes y hano llegamos a heste paraxe que por nombre se le puso nra. $S^{r a}$ del transito ques en el rio del norte $q$ [corrected in ink and replaced with the word que] con su lomeria hase un potrero y las hegas [corrected in ink and replaced with the words sus begas] habundantes de pasto y leña dista del paraxe de nra. $S^{\text {ra }}$ de la soledad hocho leguas poco mas oy meno parte [corrected in ink and replaced with the words o menos $y$ en partes] tiera doblada y en medio ahi un ohjo Caliente y ase el dho ojo el dho rio hes la tierra yntratable poblada de halgunas rancherias el habrebadero es bueno en lo alto de una loma yse colocar una $S^{\text {ta }}$ crus y para que mexor corte [corrected in ink and replaced with the word coxte] lo firme ante mi con los testigos de mi asistencia en dho dia mes $y$ haño. == (Mendoza i684 p.40)

My translation, which omits the closing formula of most diary entries (y para que mexor ... mes y haño), is as follows:

The party traveled southward and reached a spot they named Nuestra Señora del Transito, about 8 leagues (20.8 miles) distant from N.S. de la Soledad. The place was on the Rio Grande. A range of hills framed or defined the pastureland, with abundant low-lying pastures and plenty of wood. In some areas the land was rough (doblada). Between [the two named places or the range of hills?] there was a hot spring that made the river [actually the water of the spring ran into the Rio Grande, since the spring did not make the Rio Grande]. The water source (habrevadero) was good. The land was intractable. There were some rancherias of settled people. Mendoza had a cross placed on top of a hill.

There are language discrepancies between the diary entry in Províncias Internas (transcribed above) and the copy in Historia v. 298 that I followed. Some of these discrepancies reflect changes in spelling (hace, intractable, conste, año), and cases of interchangeable consonants such as $b$ and $v$ and $g$ and $x$ (parage, vegas, abrevadero).

To some this attention to detail may seem unwarranted, but it is through such practices that the researcher comes to know the writer and can detect statements that appear out of character. That is how I knew it was unlikely that version L had been written by Juan Dominguez Mendoza. 
THE NATIVE AMERICANS OF THE

TEXAS EDWARDS PLATEAU, I $82-$ I 799 
THIS PAGE INTENTIONALLY LEFT BLANK 